\title{
Fluorescent Treponemal Antibody Absorption
}

National Cancer Institute

\section{Source}

National Cancer Institute. Fluorescent Treponemal Antibody Absorption. NCI Thesaurus.

Code C95527.

An enzyme immunoassay for the detection of the bacteria Treponema pallidum, which causes syphilis. Serum is prereacted (absorbed) with protein from a non-pathogenic treponeme. 